\title{
Sialang Honey: Potency, Productivity, and Management in Musi Banyuasin (Case in Lubuk Bintialo Village, Musi Banyuasin Regency, South Sumatra)
}

\author{
Wijaya Hadi Asmara ${ }^{1 *}$, A Nurlia $^{2}$ \\ ${ }^{1}$ Zoological Society of London, Jl Diponogoro No.22 Talang Semut, Palembang, South Sumatra, Indonesia \\ ${ }^{2}$ Environment and Forestry Research and Development Institute of Palembang, Jl. Kol. H. Burlian Km. 6,5 Punti Kayu, \\ Palembang, South Sumatra, Indonesia. \\ *Corresponding author. Email: wijayaasmara76@gmail.com
}

\begin{abstract}
Forest honey is one of the Non-Timber Forest Products (NTFPs) produced from Apis dorsata. The existence of Apis is very closely related to the condition of the forest environment. In the Forest Environment $A$. dorsata has a role in helping to pollinate various plants which are also habitat for them such as the Sialang Tree. There is a dependency between A. dorsata and the forest that provides economic, ecological and social benefits. The study was conducted from January to March 2019 using qualitative methods. Data collection was carried out by observation, interview using questionnaires, in-depth interviews, and discussions with the community. The results of the study were analyzed using social analysis to explain data and facts with phenomena in the field. The results showed that $A$. dorsata had become a source of income for communities in Lubuk Bintialo Village. Honey is harvested at night regarding the culture and customs that have been carried out for generations. The entry of harvesters from outside makes the harvesting culture that has been inherited increasingly faded and extinct. At present, the productivity of sialang honey in Lubuk Bintialo Village is decreasing due to the conversion of forest into plantations. The conversion of forest caused decreasing if honey production because the availability of types of flowers as a food source of bee is increasingly limited. The conversion of forest is also causing difficulties for the community to cultivate, especially sialang trees. The community hopes for regulations both in the village and regional stakeholders or even the concession holders (private sector) to maintain the sustainability of the bees for the economic welfare of the community and sustainable environmental preservation.
\end{abstract}

Keywords: Apis dorsata, conversion of forest, forest honey, productivity

\section{INTRODUCTION}

Non-Timber Forest Products (NTFPs) are part of the forest ecosystem which have diverse role on the environment and human life [1]. One of the NTFP that is widely used by the community is forest honey. Forest honey is a type of NTFP produced by giant honey bees (Apis dorsata). One type of forest honey that is famous in Indonesia is the type of sialang honey. Sialang honey has high economic value and is one of the sources of livelihoods of rural communities [2].

Lubuk Bintialo is a village with an area is $559.27 \mathrm{~km}^{2}$ and has 967 households with a population density of 2,852 people. Most of the Lubuk Bintialo areas are located in the production forest area $( \pm 300 \mathrm{ha})$ and the Protected Forest. Forests are an important part of communities as a source of livelihood. Forests become a very crucial place for connoisseurs of its benefits. Forest villagers, people, and communities mostly access to forests to utilized the sources. Forest has been widely used for agriculture and plantations.
As many as 25,000 ha of smallholder plantations exist in this village [3].

The existence of various types of vegetation in forest areas is valuable food source for bee to produce forest honey. Forest honey is excellent product for NTFP that is utilized by the surrounding community. A lot of people in Lubuk Bintialo Village use forest honey as their source of livelihood. This study aimed to examine the potency and productivity of sialang honey produced in Lubuk Bintialo Village and to discover the management of sialang honey by the community and its problems.

\subsection{Materials and Methods}

\subsubsection{Research Location}

The study was conducted in Lubuk Bintialo Village, Musi Banyuasin Regency, South Sumatra (Figure 1). Lubuk Bintialo Village is one of the remote villages in Banyuasin 
Regency which has rich natural resources and a large of forest area [4]. Location is purposively selected based on preliminary information about Sialang Honey Collection in Musi Banyuasin Regency. The village of Lubuk Bintialo has a high potential of forest honey from A. dorsata. It is one of the centres of potential forest honey producers in subdistrict of Batanghari Leko.

Lubuk Bintialo Village has six hamlets with a population of 2,848 people and has a diverse landscape consisting of Protected Forests (HL), Production Forests (HP) and Dangku Wildlife Reserves (SM). Lubuk bintialo village has a potential landscape for the development of forest honey from A. dorsata.

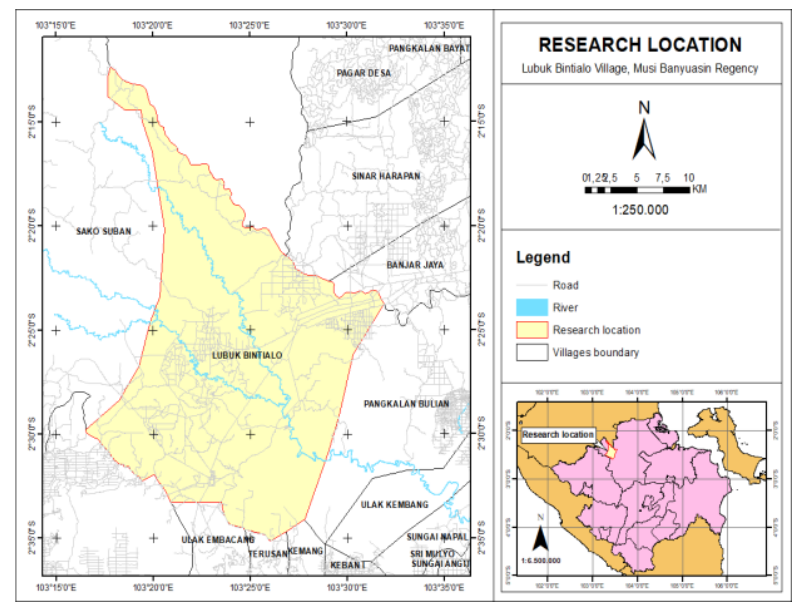

Figure 1 Research Location

\subsubsection{Data Collection}

The study was started from January until March 2019. The research was surveyed with descriptive analysis method. Data collection, in the form of primary and secondary data, is carried out through preliminary studies (pre-survey) and field surveys. Primary data were obtained based on interview to selected respondents. Selected respondents are represented by climbers, sialang tree owners and buyers of forest honey. Selected respondents were chosen using the snowball method.

Secondary data obtained through the study of literature includes literature studies of various references in the form of reports, journals, and books. References are also obtained through the internet, and other relevant sources. Field observation techniques were carried out to obtain direct information about the condition of honey management in the community including the ecological condition of the sialang tree, honey management system and the types of honey products that have the potential to be developed.

\subsubsection{Data Analysis}

Data were descriptively analysed using social analysis with 5 phases (collected, grouped, combined, interpreted and conclude [5]. Grouping and tabulating data were done to facilitate understanding of facts that occur in the field. The phenomena obtained in the field were then validated and deepened through by discussions, interviews and field observations. The relationship between the facts was then analysed through data obtained and linked to concepts used in research to understand and descripted phenomena that occur and make conclusions from research.

\subsection{Our Contribution}

This paper presents the potential, productivity, and management of sialang honey in Lubuk Bintialo Village, Musi Banyuasin Regency. Sialang Honey is one of the NonTimber Forest Products which is one of the main incomes of the village community. In this paper, we also describe the results of our research that are limiting factors that can cause a decrease in honey productivity. We hope that the results of this research can describe how the honey potential in Lubuk Bintialo Village, Musi Banyuasin Regency and can be a useful source of information for the government or related parties to give consideration in policymaking, especially related to the development of Honey Sialang. The policy taken is expected to be able to increase the income and welfare of the community, especially sialang honey farmers.

\subsection{Paper Structure}

The structure of this paper is organized as follows. Section 1 describes the background on community livelihoods related to forest honey in the form of sialang honey in Lubuk Bintialo Village, Musi Banyuasin District, describes the purpose of the research and explains the research methodology including the location of the study, research approach, data collection and data analysis conducted in this study. Section 2 presents the results of the research that has been done and answers the objectives of the research. Finally, section 4 concludes the results of the research and provides input for relevant parties regarding community expectations for the development of sialang honey

\section{RESULTS AND DISCUSSION}

\subsection{Types of Bees in the Lubuk Bintialo Village}

The type of bee found in Lubuk Bintialo Village, Musi Banyuasin Regency is a type of $A$. dorsata bee. Morphologically, A. dorsata is a species of honey bee native in Indonesia with the largest body size. Besides this species is also known to be very aggressive compared to other honey bee species found in Indonesia. A. dorsata bees belong to the Megapis subgenus with large colonies and have a larger body size (body length> $15 \mathrm{~mm}$ ) than other 
honey bees [6]. In Indonesia, $A$. dorsata is grouped into two subspecies, namely, A. dorsata dorsata inhabiting the area west of the Wallacea line, including islands in Nusa Tenggara and A. dorsata binghami which is only found on the island of Sulawesi and the surrounding islands [7-9]. Apis dorsata can be found in almost all islands in Indonesia except Maluku and Irian Jaya [10].



Figure 2 Apis dorsata honey bee

Taxonomically honeybees are classified as follows [11]:

$\begin{array}{ll}\text { Kingdom } & : \text { Animalia } \\ \text { Phyllum } & \text { : Arthropoda } \\ \text { Class } & \text { : Insecta } \\ \text { Ordo } & : \text { Hymenoptera } \\ \text { Famili } & \text { : Apidae } \\ \text { Genus } & \text { : Apis } \\ \text { Sub-Genus } & : \text { Megapis } \\ \text { Species } & \text { : Apis dorsata }\end{array}$

Honeybees are social insects that form colonies in life and have a division of tasks among their members. As a social bee, in A. dorsata colony there is a division of castes, they are the queen caste (female bees, one individual) that can lay eggs up to 50,000 eggs, workers caste (female bees, thousands of individuals), and male caste (hundreds of individuals), and several potential queen cells $[12,13]$.

A. dorsata's nest consists of only one nest comb but is very large with an area reaching more than $1 \mathrm{~m}$. The hive is also in the open, hanging from the branches of large trees such as the menggeris (Koompassia excelsa) as high as more than $10 \mathrm{~m}$ above ground level [14].

\subsection{The Potency of Sialang Trees and Forest Honey}

Sialang tree is a type of tree where forest bees ( $A$. dorsata) is hiving. The production honey is known as Sialang Honey. The sialang tree does not consist of one type of tree, but rather consists of various types of trees which are always used by bees to hive (Table 1). The type of tree chosen for nesting A. dorsata is a type of large trees with a diameter of approximately $2 \mathrm{~m}$ and a height of more than $50 \mathrm{~m}$.

The results showed that there were quite a lot of potential sialang trees in Lubuk Bintialo Village. The number of sialang trees reached 82 trees scattered in the
Lubuk Bintialo area, but most of the trees were in the concession area of PT. Sentosa Bahagia Bersama (SBB) and PT Bumi Persada Permai (BPP), only a few sialang trees are found in community-owned gardens. Each sialang tree is owned individually and can be bought and sold at a price of trees reaching 6 million rupiahs per tree. In the past, tree ownership is communal ownership because the honey produced would be enjoyed together. Changes in ownership from communal to individual occur when access to sialang trees becomes easier and forest honey products from sialang trees begin to have high economic value.

Table 1 Various species of Sialang trees

\begin{tabular}{|l|l|l|}
\hline No & \multicolumn{1}{|c|}{ Local Name } & \multicolumn{1}{c|}{ Latin Name } \\
\hline 1. & Rengas & Gluta rengas sp. \\
\hline 2. & Aro & Ficus variegata \\
\hline 3. & Menggeris & Koompasia excelsa \\
\hline 4. & Lagan & Dipterocarpus cinereus \\
\hline 5. & Durian & Durio zibethinus \\
\hline 6. & Pulai & Alstonia scholaris \\
\hline 7. & Merawan & Hopea sangal \\
\hline 8. & Meribunngan & Milletia atropurpurea \\
\hline 9. & Petanang & $\begin{array}{l}\text { Dryobalanops } \\
\text { oblongifolia }\end{array}$ \\
\hline 10. & Meranti & Shorea sp. \\
\hline
\end{tabular}

The sialang honey product business is a seasonal business which is not all year long to produce income for farmers. But the income earned by sialang farmers during the harvest period can support the family for one year. The production process is usually calculated from each sialang tree, at least in one ordinary sialang tree produces 20-30 A. dorsata honeycomb hives and can reach as many as 100 honeycombs.

Every nest can produce honey with an average net weight of $2 \mathrm{~kg} / \mathrm{hive} /$ harvest, and each nest can be harvested 3 to 5 times in one year. With an estimated number of active sialang trees as many as 50 trees and the average number of nests is 30nests/tree, the forest honey potential from the sialang tree with 4 harvests in one year can reach $12,000 \mathrm{~kg}$. The potential of forest honey from the sialang tree will continue to increase if the presence of the sialang tree continues to be maintained and preserved.

Unfortunately, the potential for sialang honey is not managed well enough. The honey farmer group organization in Lubuk Bintialo Village is not working as it should. The honey farmer group has not yet facilitated the honey farmers and only consists of three members. This causes the harvesting of honey cannot be controlled properly. In Sahilan Darusalam Village, Kampar Regency, Riau Province, farmer groups have a role in institutional, production and capital. The role of farmer groups in the 
Table 2 Difference in time to harvest forest honey

\begin{tabular}{|l|l|}
\hline \multicolumn{1}{|c|}{ Night Harvest } & Day Harvest \\
\hline - Using fire (tunam) & $\begin{array}{l}\text { - Do not use fire } \\
\text { - Perform rituals and sing songs }\end{array}$ \\
$\begin{array}{l}\text { - Without rituals and singing } \\
\text { - Do not wear thick clothes and not even dress } \\
\text { - The honey produced is cleaner because the bee } \\
\text { prood stock burns to death }\end{array}$ & $\begin{array}{l}\text { - Honey is more littered because not all bees leave } \\
\text { the hive }\end{array}$ \\
$\begin{array}{l}\text { - Can be harvested once a year (brood stock dies) } \\
\text { - Can be harvested more than } 3 \text { times (each one nest) }\end{array}$ \\
\hline
\end{tabular}

institutional sector is to increase the income of honey farmers and to participate in forest honey development programs supported by the government to increase farmers' knowledge about forest honey. The role of farmer groups in the production sector is to maintain the quality of production by implementing a drainage system, and the role of farmer groups in the capital sector is that farmers get the main capital independently from the community [15]. Therefore, the farmer group is an important institution that must be built by honey farmers in Lubuk Bintialo Village in order to increase income from the forest honey.

\subsection{Sialang Honey Harvesting Patterns}

In the past, sialang honey was only harvested at night during the dark moon or only part of the moon's visible appearance. In one honey-taking group, there is one person who is called a handler. This handler will be responsible for climbing trees while assisting. Chanting becomes a mandatory thing that must be done before the honey extraction process. A song is a form of a request for permission to tree keeper and queen bee. Like the person who will go into someone else's house that must be excused and permission before, so is analogous in the process of taking this sialang honey.

In addition to being a singer, another thing that must be obeyed by honey takers is that the tools used to cut honeycomb must not use iron tools. The tools used must be made of wood or just using hands. The community believes that if these things are violated it will bring misfortune and mystical events to those who take the honey.
Over time, the tradition of harvesting at night began to be abandoned. Singing is also no longer done by the community. People have started to switch to take honey during the daytime. Daytime honey extraction is carried out due to the influence of harvesters from outside the village. Harvesting during the day is considered to provide many advantages besides safety reasons. Honey harvesting that is done at night is very many obstacles because of many disturbances such as strong winds and disturbances from wild animals such as snakes, tigers and bears. These reasons are reasonable for the village community, so the community began to switch to take honey during the day.

There are some differences in harvesting during the day harvest and night harvest. Each method of harvesting has advantages and disadvantages. In detail the differences in harvest time are presented on Table 2.

The honey obtained is then cleaned from bees that are in the nest both breeders and tillers. The honeycomb is then cut into pieces to facilitate processing. Nest cutting is done to speed up the process of removing honey from the hive. Squeezing honey is done directly by hand, then honey is filtered using a cloth or waring $1 \mathrm{~mm}$ in size and the squeezed honey is collected in a container usually in the form of jerry cans or a 60-liter closed bucket.

\subsection{Potential Profit of Productivity of Sialang Honey}

Sialang honey product business is a seasonal business that does not produce income for farmers all year but the income earned by sialang honey farmers in the harvest period can support the family for one year. Harvesting is

Table 3 The Profit from honey forest

\begin{tabular}{|l|l|c|}
\hline \multicolumn{1}{|c|}{ No } & \multicolumn{1}{c|}{ Description } & Amount \\
\hline 1 & Total honey production per month (kg) & 400 \\
\hline 2 & Selling price of honey/kg (Squeeze honey) & 60,000 \\
\hline \multicolumn{2}{|c|}{ Total advantage of honey (IDR/month /group) } & $24,000,000$ \\
\hline$*$ Total honey profits (IDR/month/person) & $8,000,000$ \\
\hline
\end{tabular}

* The profit obtained is gross profit that has not been reduced by operational costs 
done in one group consisting of two to three people. Therefore, the results obtained will be divided into 3 parts. With an average production of $400 \mathrm{~kg}$ per harvest and the price of honey Rp. $60,000 / \mathrm{kg}$, then the income the harvester will get is as follows in Table 3 .

Besides honey, another product that can be obtained is honey wax. Honey wax is produced by boiling it with hot water, the remaining honey is squeezed until it melts. After that, it is cooled in a container until it freezes into a solid form of honey wax. With the price of honey wax Rp. $50,000 / \mathrm{kg}$ and the potential for honey wax is $100 \mathrm{~kg} / \mathrm{month}$, honey wax can increase farmers' income by $20 \%$ of the income derived from forest honey. The amount of income earned by farmers every month indicates that the forest honey business is feasible to do. An appropriate policy is needed so that farming can be maintained.

\subsection{Factors Causing the Decreased in Honey Productivity in the Lubuk Bintialo Village}

Interviews showed that the main factors causing the decline in honey productivity were changes in the landscape and the presence of honey harvesters from outside the village. Following is a description of each of these factors.

\subsubsection{Environmental Change}

The existence of $A$. dorsata honey bees is strongly influenced by the surrounding vegetation. Forest environment with various types of vegetation has the potential to feed honey bees. Flowers from various types of forest plants are the main source of bees in producing honey. Not only do bees benefit from the presence of forests, but forest plants also absorb benefits from the presence of bees as pollinators for forest plants. This process of interdependence has another positive impact on humans around them.

Before the concession entered the village area, the forest area in Lubuk Bintialo Village was a fairly thick forest area. Access to the sialang tree is difficult because there is no access to the cultivation of the land, therefore ownership of the sialang tree is communal ownership where the honey is used for the common good.

In 2000, environmental changes began to occur. Land concessions have transformed forest areas into agricultural and plantation lands. Access to sialang trees in the forest area is more easily accessible by the community. This causes a change in tree ownership from communal to individual. Not only the trees claimed by the community but also the surrounding land. The development of productivity plants such as rubber and palm oil began to develop on these lands and began to suppress the development of sialang trees. Land concessions also cause the existence of sialang trees that are currently widely available around HTI (Industrial Plantation Forest) companies PT. Bumi Persada Permai (BPP) and PT. Sentosa Hagia Bersama (SBB). More than $80 \%$ of sialang trees are in the company's concession area.

In 2016, there was a change of plants in the company area. PT BPP which previously planted an acacia tree then replaced its plants with eucalyptus trees. The substitution of this plant has an impact on the productivity of sialang honey. According to the community, honey yields have decreased significantly since the change of these plants.

Acacia trees have sympodial branches where branch growth will be more dominant than the main stem and produce more leaves and flowers, it will produce nectar on acacia trees will be more abundant. While eucalyptus (Eucalyptus) trees are generally slightly slender and light in crowns. Branching more to make the upper corner, rarely and not too thick leaves. Types of eucalyptus tree branches enter into a monoidal branching where the main stem (primary) has faster growth than its branches and has a larger and longer size. These characteristics then influence the development of leaves and flowers produced by eucalyptus trees. The slow growth of leaves and flowers makes a little nectar production.

Apis dorsata honey bees has the ability to fly up to 10 $\mathrm{km}$ to search for nectar. Although able to fly far, but the location of distant feed can reduce the efficiency of the bee to produce honey in one time period. Forest as a supporter in the main provider of nectar is needed by bees to survive in the environment.

\subsubsection{The Entry of Harvesters from Outside the Village}

The economic value of sialang honey began to attract interest from harvesters from outside the village. Harvesters from outside are generally derived from honey collectors. They bring innovation in taking honey. Honey which was originally only taken at night, is now starting to be taken during the day. Harvesting during the day is considered more profitable because the bees do not burn by fire so that each nest can produce honey for at least 3 months (three times harvest) while for harvesting at night (using fire) can only be harvested once a year (1 hive 1 time harvest), harvesting at night can slow down the return of bees to nest because bees are very anti-smoke (smoke or odor that sticks to the stem). The innovations brought by the harvesters from outside the village caused the culture of the inherited harvest to fade and become extinct, and the extraction of honey was exploited for economic gain. Competition that occurs with honey harvesters from outside the village causes the productivity of honey produced by harvesters from the Lubuk Bintialo Village is decreasing.

\section{CONCLUSION}

Forest honey produced by $A$. dorsata bees had become a source of income for communities in Lubuk Bintialo Village. Harvesting honey is done with two pattern they are night harvest and day harvest. Sialang honey has high 
(PLA) di Desa Terpencil: Peran LSM PROVISI Yogyakarta dalam Pemberdayaan Masyarakat di Lubuk Bintialo, Sumatra Selatan, J. Pemberdaya. Masy. Media Pemikir. dan Dakwah Pembang, 10(1) (2017) 97

[5] R. K. Yin, Qualitative research from start to finish, vol. 53, no. 9. New York: The Guilgorf Press, 2011

[6] T. D. Seeley, Honeybee Ecology: A Study of Adaptation in Social Life. Princeton, New Jersey, United Kingdom: Princeton University Press, 1985

[7] S. F. Sakagami and T. Matsumura, Apis Laboriosa in Himalaya, the little-known world largest honeybee (Hymenoptera, Apidae), Insecta Matsumurana, 19 (1980) 47-77

[8] R. Raffiudin and R. H. Crozier, Phylogenetic analysis of honey bee behavioral evolution, Mol. Phylogenet. Evol. 43(2) (2007) 543-552

[9] H. R. Hepburn and S. E. Radloff, Honeybees of Asia, Honeybees Asia, 2011, 669p

[10] F. Ruttner, Biogeography and Taxonomy of Honeybees. Verlag Berlin Heidelberg Newyork: Springer, 1988.

[11] D. J. Boror, C. A. Triplehorn, and N. F. Johnson, Pengenalan Serangga. Penerjemah: Soetiyono Partosoedjono. Yogyakarta: Gajah Mada University Press, 1992

[12] N. Q. Tan, Biology of Apis dorsata in Vietnam, Apidologie, 38(3) (2007) 221-229

[13] A. L. Beaurepaire, B. F. Kraus, G. Koeniger, N. Koeniger, H. Lim, and R. F. A. Moritz, Extensive population admixture on drone congregation areas of the giant honeybee, Apis dorsata (Fabricius, 1793), Ecol. Evol. 4(24) (2014) 4669-4677

[14] S. Hadisoesilo, Keanekaragaman spesies lebah madu asli Indonesia, Biodiversitas, 2(1) (2001) $123-128$

[15] A. Wispinaldo, M. Marhiansyah, and T. Arlita, The role of the farmers group, In The Utilization of Wild Honey in Sahilan Darussalam Village, Gunung Sahilan District, Kampar Regency, Riau Province, JOM Faperta UR, 3(2) 2016

[4] A. F. Silmi, Participatory learning and action 